\title{
Knowing Is Belonging : Recognitional Deixis and Emergence of Common Ground in Religious Conversion
}

\section{Khachaturyan, Maria}

2019-03-01

Khachaturyan , M 2019 , ' Knowing Is Belonging : Recognitional Deixis and Emergence of

Common Ground in Religious Conversion ' , Signs and society , vol. 7 , no. 2 , pp. 186-216 . https://doi.org/10.1086/7

http://hdl.handle.net/10138/304932

https://doi.org/10.1086/702441

publishedVersion

Downloaded from Helda, University of Helsinki institutional repository.

This is an electronic reprint of the original article.

This reprint may differ from the original in pagination and typographic detail.

Please cite the original version. 


\title{
Knowing Is Belonging: Recognitional Deixis and Emergence of Common Ground in Religious Conversion
}

\author{
Maria Khachaturyan, University of Helsinki
}

\begin{abstract}
This article explores the situated usage of recognitional deixis, a prominent feature of the religious register of the Catholic community of Mano, Guinea. Recognitional deixis is understood to be the marking of referents as known and recognizable by the interlocutors, typically belonging to their common ground. While deictic markers are known to reflect a specific speaker-hearer-object configuration, I suggest reversing the indexical relationship and claim that instead of indexing contextual relationships (context presupposition), deictic markers rather project them in a performative fashion (context creation). In the study in question dealing with the marking of common ground by recognitional deixis, what gets projected is a presupposition of shared knowledge. Because of the dialogic orientation of recognitional deixis, as a consequence of presupposition projection, the speaker and the addressees emerge as knowledge-sharing co-insiders. This, in turn, contributes to a performative creation of a community of co-insiders-a religious community sharing religious knowledge.
\end{abstract}

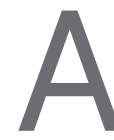

remarkable feature of key political texts of the history of the United States is the use of the first person plural pronoun we-as in "We hold these truths to be self-evident" in the Declaration of Independence; in "We the People of the United States," the opening phrase of the Constitution; or in "we are engaged in a great civil war" of Lincoln's Gettysburg Address. The

Contact Maria Khachaturyan at University of Helsinki, Humanities Programme, Unioninkatu 40, B620, Helsinki, Finland, 00100 (maria.khachaturyan@helsinki.fi).

I am deeply grateful to the Mano people and to the Mano Catholic community for teaching me their language and sharing their faith. I am especially grateful to Christophe for all the time we spent together and Jean-Pierre for the insightful conversations. Previous versions of this article were given at the Intersubjectivity in Interaction Work in Progress seminar and at the Linguistic Anthropology Working Group at Helsinki University, as well as at the Politics of Participation conference at the Helsinki Collegium for Advanced Studies. I

Signs and Society, vol. 7, no. 2 (Spring 2019). (c) 2019 by Semiosis Research Center at Hankuk University of Foreign Studies. All rights reserved. 2326-4489/2019/0702-0003\$10.00

186 
little inclusive word we, as Michael Silverstein called it in his analysis of the Gettysburg Address (2003), creates the very group it refers to; in particular, as in the Declaration of Independence, the "we" who solemnly publish and declare that "these united colonies ought to be free and independent states" free themselves, create themselves as freed "at the instant of and by the signature" of the declaration (Derrida [1986], 9; cited in Lee [1997]). All these "we" enact, or perform, a certain subjectivity, even if the performative momentum differs in case of each text. In other words, "we" projects a certain framework of coengagement in a political process.

That "we" seems to be a peculiar feature of American political texts. It is not found in key contemporaneous texts in other places, such as the French Declaration of the Rights of Man and of the Citizen produced some 20 years after the American Declaration of Independence, for which the latter served as an important precedent. The French declaration begins with "Les représentants du peuple français" (The representatives of the French people), not "Nous, les représentants du peuple français" (We, the representatives of the French people). Nous is not found in the French constitution. "Uns Kommunisten" (We the communists) appears only later in the Manifesto of the Communist Party, which begins instead as a third-person narrative.

However, the performative work that "we" does is hardly unique. As I will argue in this article, what "we" does could be analyzed as an instance of indexical performativity. ${ }^{1}$ My focus will be on indexical grammatical categories, or deixis, although the analysis could be extended to nongrammatical indexicality as well.

To borrow William Hanks's definition, “deictic systems define points of intersection between linguistic structure and the social settings in which speech takes place" (2011,315). More specifically, deictic categories reflect the relation between, on the one hand, the indexical origo, or the participant framework and the roles within it occupied by the communicative agents (the speaker, the ad-

am very thankful to the audiences for their comments, especially to Elina Hartikainen, to Johanna Nichols, and to Asif Agha. I appreciate insightful suggestions from Joel Robbins, Arnulf Deppermann, and Alexei Yurchak during earlier stages of manuscript preparation. I thank the reviewer for helpful comments and Robert Whiting for language revision. The last but not the least, I am grateful to William Hanks for continuous inspiration and for his contagious passion for deixis.

1. Performativity in language is best known, and studied, in the form of performative speech acts first brought into attention of modern Western scholars of language by Austin (1962) (although much studied before Austin, in particular, in medieval scholasticism, see Rosier-Catach [2004]). The language's potential of bringing into being what it names emerges in (lexical) categorization as action ("symbolic power" of Bourdieu [1991]; see also Ambroise [2009]) or in indexical projection of relationships (Friedrich [1972]; on performative workings of indexicality in ritual, see Tambiah [1985], esp. 157-66). It is in this latter, larger sense that I am using the term performativity. 
dressee), and, on the other hand, the objects of reference. Typically, such a configuration implies that the origo-object relation is always given and exists prior to the utterance in question. The deictic markers index, as it were, the existing relation between the origo and the object.

In an illuminating article by Paul Friedrich (1972), it was shown that deictic categories - in this case, second-person pronouns with an honorific function in Russian - have the capacity of what he called "switching," or "breakthrough." By giving several illustrative examples from Russian prose from the two last centuries, Friedrich argues that fictional characters' subtle choice of the pronominal form is an effective means to index the degree of formality of the relationship and relative social position of the interlocutors. But, what is more, that same choice can contribute to interpersonal dynamics, thus providing a "breakthrough" in the relationship between the characters. In the latter case, instead of indexing a given interpersonal relationship, the deictic form projects it. That inverse relation between a deictic form and the context of its usage-breakthrough, projection, instead of indexing - is another example of what I call "indexical performativity": by its very utterance, a deictic form adjusts the context of its use.

In addition to the speaker and addressee pronominal forms, a wealth of other deictic markers can be used in the performative function, some of which directly contribute to participatory dynamics. I turn now to my main object of studythe demonstratives as they are used by members of the Mano Catholic community in West Africa.

Conversion to Christianity in Guinea, and in the Forest Guinea region in particular, is very much an ongoing process. With competition from numerous Protestant denominations, limited resources, and little institutional support, the Catholic Church in Guinea in many respects could be characterized as grass-roots. The life of the community depends crucially on the activity of ordinary members and much less on the church hierarchy. From gathering and controlling resources to the very efforts of proselytizing - all these activities are essentially done by laypeople. The semi-institutionalized nature of the church is especially apparent in the organization and religious practice of the Catholic community of the Mano ethnic group and in particular in their usage of religious documents. Many of the routine religious texts, such as prayers and chants, were translated by Mano laymen, and new versions continue to be created.

Most unexpectedly, while a translation of the New Testament into Mano, published in Liberia (UBS 1978), is available and has a certain amount of usage by the community, more often than not the Mano prefer to translate them- 
selves, using as a source the French missal. ${ }^{2}$ Thus, while the order of worship and the ritual performance remain regimented and predefined, as is typical of Roman Catholicism, the readings from the Bible-along with the sermon, of course-become the main sites of improvisation and also of stylistic differences between the speakers. These spontaneous oral Bible translations and the particularities of their language are the main objects of this study.

Special attention is paid to the deictic marking of nominal expressions. Consider the following excerpts from a recording of a Sunday celebration: ${ }^{3}$

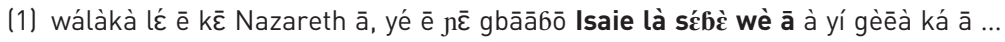

'(In) the house of God that was in Nazareth, when he finished reading THAT speech of the book of Isaiah ...'

This passage is a translation of a phrase introducing Luke 4:21-30 (recorded on January 31, 2016). It is not part of the gospel but rather a free summary of the context in which to situate the subsequent verses. The French original and its English translation are as follows:

[En ce temps-là], dans la synagogue de Nazareth, après la lecture du livre d'Isaïe, [Jésus déclara] ...

[At that moment], in the synagogue of Nazareth, after the reading of the book of Isaiah, [Jesus declared] ...

In the Mano translation, the expression Isaïe là sćbè wè is followed by the distal demonstrative $\bar{a}$ : THAT speech of the book of Isaiah. The demonstrative is not used in an exophoric function, pointing to objects present in the interactive scene, as, naturally, the speech of the book of Isaiah is an abstract notion. Nor is it an example of the anaphoric function of pointing to referents that were introduced in prior discourse; because this utterance happens to be at the very beginning of the reading, there was no prior discourse on the topic, nor was the book of Isaiah read on that day. What we have here could be characterized as an instance of the recognitional function of the demonstratives. Recognitional

2. In the Roman Catholic Church, the readings from the Bible are not chosen by the priest but are prescribed by the missal, which is a collection of religious texts intended for reading on Sunday and on holidays. The missal is divided into three liturgical years, A, B, C, so the readings will repeat every three years, with the exception of the readings for the major holidays, which are the same every year. One catechist orally translates from a missal that was itself translated (most likely, from French) into Kpelle, a neighboring language that many Mano use as a second language and that is also the native language of all the priests serving in the region. Oral Bible translations have not received much scholarly attention, with the notable exceptions of Handman (2014) and Schieffelin $(2007,2014)$.

3. Capital letters indicate a literal translation of the demonstrative, THIS for the proximal we and THAT for the distal $y \bar{a}$. Shorter examples are given with a full gloss and a free translation, while longer examples are given with a free translation only. 
deixis (Himmelmann 1996, 206; Diessel 1999, 9) is used where the identifiability of the referent relies essentially on the ability of the addressee(s) to recognize it on the basis of her and the speaker's common ground. But the example given above is problematic in this regard. Can the Mano congregation, including the prayer leader who read and translated that Biblical passage, really know the "speech" of the book of Isaiah-specifically, what it was exactly that Jesus read from the book of Isaiah? The content of his reading was indeed mentioned in Luke 4, but the corresponding passage (Luke 4:18-19) was not included in the reading. I argue instead that recognitional marking in religious language does not describe a real state of affairs, a recognizability of the referents, but rather is performative: the referents do not actually have to be known by everybody, but they are presented as if they were known. As I argue, recognitional marking serves to performatively project background knowledge, which is intrinsically collective, and forms a common ground of the religious community of Mano Catholics.

On a different level, I suggest looking at the religious common ground as one of the parameters defining a collective conversion. In contrast with cases where collectivities are indexed (and projected) by straightforward labels of groups ("we," or "this nation"; Silverstein 2003), in this case the operation is more complex: from recognitional deixis, to projection of common ground, and to projection of community sharing that common ground. While this approach does not address major sociocultural transformations accompanying conversion, or explain why conversion happens, it elucidates how conversion essentially relies on collectivities and how these collectivities are indexed by specific grammatical marking - one of the defining features of the religious register - and thus are performatively brought into being in ritual speech.

I begin the analysis by providing a sketch of the background of Mano conversion. I suggest looking at conversion on a community scale as a "group work."

I then turn to my case study and analyze the way collective background assumptions are brought into being in Mano religious language by means of specific grammatical marking. The empirical core of my argument is a study of demonstratives used in the recognitional function. I first give an overview of the demonstrative system and the way recognitional marking is used outside the church context. Then I discuss a series of examples of recognitional deixis in church. I conclude by pointing to some stylistic differences between speakers. I show that the frequency of recognitional marking is dependent on the existing relationships in the community and the individual sense of in-group membership.

In the second section, I proceed to a theoretical discussion arguing that recognitional marking could be seen not as indexing of specific properties of 
context - mutually known referents as part of the common ground - but rather performatively projecting contextual features, namely, the existence of (the community sharing) that common ground. Following the insight of Silverstein (1976) and other scholars of indexical performativity, I argue that recognitional deixis has a context-creating performative capacity. I next formulate an approach linking religious conversion to religious common ground, emphasizing the centrality of knowledge in religious practice (Asad 1993). I then show how common religious knowledge is connected to community building. I next suggest looking at the assertion of common knowledge as a performative strategy, elaborating on the conception from Yurchak (2005) and Nichols (1988). Finally, I focus on how common ground projection becomes a function of propositional stance and how it shapes, and reflects, social relationships.

\section{Mano Catholic Conversion: Background}

The focus of my study is the Catholic community of the Mano. ${ }^{4}$ Mano is an ethnic group that counts about 390,000 members spread over southeastern Guinea (the Forest Guinea region) and northern Liberia, and my field site is in Guinea, with 85,000, or about 20 percent, of the total Mano population. ${ }^{5}$

The evangelization of the Mano did not go hand in hand with colonization. The Roman Catholic missionaries from the Society of the Missionaries of Africa (known as White Fathers) were at odds with the colonial administration (Loua 2008) and later with the government of independent Guinea (Vieira 2005). Therefore, similar to other cases discussed in the literature on anthropology and history of Christianity, such as the Urapmin in Papua New Guinea (Robbins 2004), but in contrast to the Tswana in South Africa (Comaroff and Comaroff 1991) or conversions in coastal Africa (Foster 2008), the proselytizing effort was deprived of support from the secular power. Furthermore, the missionary presence among the Mano was short. The missionaries arrived in the Mano zone in the early 1940s (Lelong 1949). In 1967, all the Guinean missionaries were expelled, as the government of independent Guinea was insisting on the Africanization of the clergy. As a result, in the late 1960s, the whole region of Forest Guinea, including but not limited to the Mano zone, had just two African

4. This work is primarily based on 1.5 months of fieldwork in Guinea in 2014, 4.5 months in 2015-16, and 1.5 months in 2017-18 supported by the LLACAN, CNRS, France, a grant from Fondation Fyssen, France, and by the University of Helsinki, Finland, respectively. Some examples are drawn from a corpus of natural Mano texts that I have been recording in Guinea since 2009. A grammar sketch of Guinean Mano can be found in Khachaturyan (2015).

5. My main field sites are the city of Nzerekore and the villages of Yalenzou, Nzao, Godi, Karana, and Bounouma, all within a 15-kilometer range from Nzerekore. 
priests, and neither of them spoke Mano. Even today there is only one active Mano-speaking priest in the region. Thus, the history of Mano conversions contrasts sharply with the history of missionary presence in Central America, which lasted for centuries (Hanks 2010), but is comparable to the conversions in Papua New Guinea (Robbins 2004; Schieffelin 2007).

Today, according to the evangelical organization Joshua Project, no more than 4 percent of Mano in Guinea (or about 3,200 individuals) have converted to Christianity, ${ }^{6}$ of whom about 80 percent are Catholics, which makes Mano Christians a fairly small population. My own estimations are even more moderate: I would suggest 500 as an estimate of the active core of Mano Catholics in Guinea. Converted and nonconverted Mano live in the same villages. It is rarely the case that a whole family, even a nuclear family, chooses to convert to Christianity; many members were brought to their church by a sibling, an uncle, or even a friend, and very few were baptized at birth. In addition, there is a great denominational diversity: the Evangelical Church seems to be the most powerful, and the most resourceful, among Protestant denominations; other Protestant groups include Jehovah's Witnesses, Foursquare, and Shekinah.

Mano Catholic converts seem to be quite comfortable with pre-Christian religious practices. Thus, they participate - actively or as observers and partakersin traditional ceremonies of sacrifice to the ancestors; many of them have passed the initiation ritual. This observation corresponds to the general tendency of the Catholic Church to (partly) incorporate, and accommodate, pre-Christian cultural practices. Conversion is visibly a long process: many Manos I encountered have attended the church service for many years without receiving baptism, and although members of the congregation do talk about the importance of their decision to join the church, I have not heard any sharp discontinuity narratives similar to those produced by converts to Protestant denominations.

The group of converts is socially very diverse: some of them are old enough to have been baptized in colonial times, and they are usually well-educated men and women retired from the public sector. The majority of Mano Catholics, however, are farmers who were born after the missionaries left. They are usually much less mobile, living in the same village their entire lives; some of them barely speak French. Thus, conversion to Christianity among the Mano is still a peripheral process involving relatively small and diverse groups and is unlikely to be explained by the social transformation of the microcosm of a village community opening up to the world, a framework that Horton suggested for African conver-

6. See https://joshuaproject.net/people_groups/16121. 
sions (1971, 1975a, 1975b). Moreover, as I argue, conversion to Catholicism is predicated in many ways on small village communities, which are the main domain of church-related activities but also represent a group of people implicitly sharing some body of knowledge.

\section{Mano Catholics as a Community}

As mentioned above, conversion among the Mano does not rely on stable social groupings, such as family, and seems to be an individual choice. Individuals also play an important role in the life of the community. Formally trained catechists and especially prayer leaders are pivotal in all respects, as they gather community members and guide Sunday celebrations. Specific community members may donate land or even sponsor the construction of the church building.

At the same time, an important level at which Catholic identity is conceptualized is the level of the universal church. The common trope is to emphasize the universal message (wálà léwè 'the word of God'), which eliminates any difference between the ritual performance in Yalenzou, Guinea, and in Rome (the same things are said and done) but also rules out any possibility of error in performance (if by definition anything said in church by a responsible person is the word of God, there cannot be any mistake).

In discussions with me, some community members mentioned that the Roman Catholic Church is the "mother church" and that it has no internal divisions, in contrast with Protestant sects that continue to be created. It seems, however, that the Catholic identity is not so different from the Protestant identity. Catholics and Protestants have a strong common Christian denominator to the extent that a distinction between them is not made by the non-Christian majority; they also mobilize together in the ethnoreligious conflicts with the Muslim Manding in the region. ${ }^{7}$ There are several terms used to refer to Christians: église mìa 'people of the church' (< French église), wálà mì̀ 'people of God' (wálà 'God'), kānà mìa 'people of the prayer' (kānà 'prayer'). None of these terms seems to be dedicated to Catholics or Protestants except for the latter, which is specifically Catholic but rarely used among the Mano.

The most important level, however, at which most of the church-related activities and talk are situated is that of the village community. For major holidays, such as Christmas, rice and money are collected from community members,

7. See a report on 2013 clashes, https:/www.aljazeera.com/indepth/features/2013/08/201386154259622267 .html. 
and the women prepare the festival meal. Money is collected the same way to cover the transportation of a visiting priest or a prayer leader.

In some villages, such as Nzao, the community was able to construct the church, having organized common agricultural labor. Agricultural labor is typically done by workgroups, which are called g’̀: the term is also used for all social groupings with a more or less stable character, such as a credit union. A church community is often conceptualized in terms of a gj̀‥ For example, when a person wants to get everybody's attention and establish silence at a workgroup meeting, she will say out loud the name of the group and then the interjection $w \bar{a} y \bar{e}$. Similarly, the president of the Yalenzou church community says, "Krístà wāyēe," where Krístà functions as the name of the "workgroup." The conception of the universal church in terms of work is also reflected in one of the versions of the creed, where "I believe in the holy catholic church" is rendered by yē $6 \bar{c}$ mésía kátólikáa 'saint catholic work'. Likewise, the importance of group work is seen in the polysemy of the word t'́n', which means both 'law' and 'penalty, punishment'. While an old church member explained to me that one of the reasons why people do not come to the Catholic church is the t'jy 'church laws' in the first sense, by which he means the condemnation of heavy drinking or of consulting "charlatans," for one of the prayer leaders the "church law" preventing people from joining the church is the penalty for nonparticipation in agricultural labor to which church members are bound.

I focus on the way group membership is predicated by discourse practices. I show how, when some piece of knowledge — specifically, Christian — is framed as known by all members of the congregation, the very existence of the congregation arises as a performatively established presupposition. I will now discuss the analysis of recognitional deixis in the Mano religious register. I will first sketch out the Mano deictic system before turning to the recognitional function of demonstratives first in everyday Mano and then within the church.

\section{An Overview of the Mano Deictic System}

Mano has no grammaticalized definiteness category; in other words, it does not have an obligatory article or similar marking that would be used with definite noun phrases. Even definite referents can be expressed by a bare nominal without any special marking. Instead, Mano has five demonstratives: t'́ $\bar{j}$, dì $\bar{a}, w \bar{\varepsilon} \sim 6 \bar{\varepsilon}, y \bar{a} \sim$ $\bar{a} \sim y \bar{a} \bar{a}$ (which has several other variants, such as yéā or téā) and kílīa $\sim$ kílībe. Tó and $\underset{\sim}{i \bar{a}}$ are proximal and distal demonstratives, respectively, used to refer to objects that are typically (but not always) present at the interactive scene and visible; 


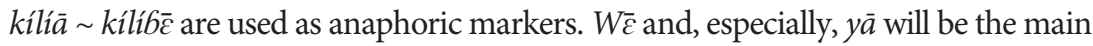
focus of this article.

When used adnominally, $w \bar{\varepsilon}$ and $y \bar{a}$ cover all the demonstrative functions suggested by Himmelmann (1996): they are used both in exophoric (referring to objects present on the interactive scene) and endophoric (referring to objects not present on the interactive scene) functions, including discourse-referential, anaphoric, recognitional, but also cataphoric functions. In the exophoric function, $w \bar{c}$ is used to refer to proximal objects, while $y \bar{a}$ is used to refer to distal or invisible objects; in the endophoric function, the two markers are largely interchangeable in discourse.

I begin with the exophoric function in which the demonstratives $w \bar{\varepsilon}$ and $y \bar{a}$ compete with t's $\bar{y}$ and $d \underset{\sim}{\mathrm{a}}$, proximal and distal demonstratives, respectively. The key distinction between the two pairs is that the former pair is used for discourse-old, familiar, cognitively accessible referents, while the latter pair is used for discourse-new referents. Example 2 is taken from my notes of a spontaneous conversation. An old man offered his classificatory son (a youngergeneration male within the same lineage) an agricultural field. The old man, the younger man's wife, and I went to look at the field. My notes do not mention whether it was the first time the woman had seen the field; in any case, it certainly was much discussed in the family. With a pointing gesture, the old man says:

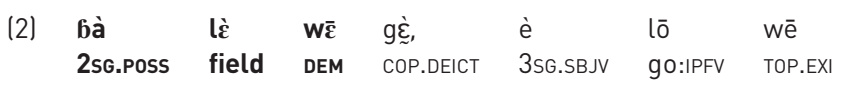

'THIS field of yours, here it goes.'

The speaker introduces the field with the demonstrative $w \bar{\varepsilon}$. The field is clearly visible and pointed to (therefore, we are dealing with an exophoric function). In contrast, when a few minutes later the two and some other men start to clear the field with machetes, a bush to be cut down was pointed to with the words mì t's 'this guy'. The crucial distinction between $w \bar{\varepsilon}$ and t's $\bar{y}$ is that t's $\bar{y}$ indexes discourse-new referents (this bush I am drawing your attention to), while $w \bar{\varepsilon}$ indexes familiar, cognitively accessible referents recognizable by both interactants (this field that you now see and that we much talked about). In this sense, $w \bar{\varepsilon}$ is used at the very same time in exophoric function (pointing to referents on the interactive scene) and endophoric, recognitional function. Thus, $w \bar{\varepsilon}$ does not characterize the referent in terms of spatial relationship to the origo alone: spatial, but also cognitive, access to the referent get intermingled (a theory of deixis 
as a measure of multidimensional access to referents was developed by Hanks 2005, 2011, inter alia). Another example illustrates a similar situation. In response to speaker A's command to "Go fetch some water," speaker B replies:

(3) yií yā?

'THAT water?'

Example 3 was recorded in the familiar setting of a household. The speaker is having dinner and is asking his son to bring him some water. They have two types of drinking water available: water from the well stored in a jar in the hallway and treated mineral water in disposable plastic bags stored in their guest's bedroom. The boy asks his father whether he means mineral water and points across to the wall of the room where the mineral water is stored. The water is invisible to the interlocutors but still present in the imagined interactive space, whence the gesture and the exophoric function. Crucially, the referent is cognitively available to the interlocutors from their common knowledge of the household and the objects within it. Although it just emerged as a topic of conversation, the demand to fetch some water is so much part of the daily routine that the referent was not framed as discourse-new (in which case the demonstrative $d \underset{\sim}{i} \bar{a}$ would likely be chosen), but rather as given. Note that the form $y \bar{a}$, instead of $w \bar{\varepsilon}$, is chosen, since the referent is invisible.

Another example comes from a recorded narrative for which video is not available. However, the example is taken from reported speech, and, given the context, the exophoric function is the most plausible:

(4)

$\begin{array}{llllll}\text { mī } & \text { téá } & \text { à } & \text { gā } & \text { wáá } & \text { ká. } \\ \text { person } & \text { DEM } & \text { 3SG } & \text { death } & \text { NEG }>\text { COP }>3 S G & \text { with }\end{array}$

'THAT person, he is not dead.'

The example is taken from a story told by a prayer leader about how he nearly died in a motorbike accident. In the example, 'that person' is the current speaker himself. The quoted speaker is a chief gendarme who is observing the state of the prayer leader. Although it is impossible to deduce the relative placement of the gendarme and the prayer leader and the motivation of the choice of the distal demonstrative (téa a variant of $y \bar{a}$ ) over the proximal one, what is important is that the prayer leader is the main protagonist and the main object of the reported discussion, so, again, it is a prominent and discourse-old referent. 
The demonstratives $y \bar{a}$ and $w \bar{\varepsilon}$ are also used in endophoric functions. An especially common use of these demonstratives is in the anaphoric function, as a reference-tracking device. Thus, in the following example, the demonstrative $6 \bar{\varepsilon}$ (a variant of $w \bar{\varepsilon}$ ) indexes the main protagonist in the story, a child named Gbamo Se Se:

$\begin{array}{lllllllll}\text { (5) Yēlć } & \text { gbāā } & \text { néfú } & \mathbf{6} \bar{\varepsilon} & \bar{e} & \text { gó } & \text { gbāā } & \text { lūú } & \text { néyżīpíé ... } \\ \text { then } & \text { now } & \text { child } & \text { DEM } & \text { 3SG.PST } & \text { leave } & \text { now } & \text { bushes } & \text { evening }\end{array}$

'Now THIS child went to the field in the evening ...'

Yet another example is taken from a story about a greedy spider who wanted to participate in the festivals in seven villages. (When he learned that in all the villages the holidays would happen on the same day, he immediately got up and went to see the organizers of the festivities. "I want to bring seven ropes so that they are attached to my body and a tag-end is brought to every village," he said. When the day came, he went out and stood in the middle of the road.) The demonstrative $y \bar{a}$ indexes the noun phrase referring to the seven villages that were previously mentioned:

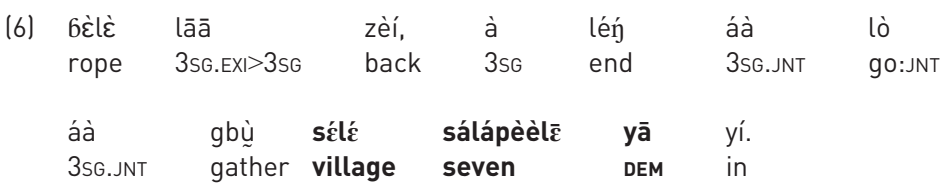

'The rope is around his waist, its tag-ends reach THOSE seven villages.'

The following example is an illustration of the discourse-referential function. It is the final example in the same story about a greedy spider. The demonstrative $b \bar{\varepsilon}$ is used to frame the noun phrase that refers to the entire story that has just been told.

\begin{tabular}{|c|c|c|c|c|c|c|c|}
\hline $\begin{array}{l}\text { Pìà } \\
\text { story }\end{array}$ & $\begin{array}{l}\mathbf{b} \bar{\varepsilon} \\
\text { DEM }\end{array}$ & $\begin{array}{l}\text { yíbòàyí } \\
\text { meaning }\end{array}$ & $\begin{array}{l}\text { lદ́ } \\
\text { 3SG.EXI }\end{array}$ & í 2 sG.conJ & $\begin{array}{l}\text { nāá } \\
\text { want:cond.cond }\end{array}$ & $\begin{array}{l}\mathrm{i} \\
\text { 2sG.CONJ }\end{array}$ & $\begin{array}{l}\mathrm{p} \bar{\varepsilon} \\
\text { thing }\end{array}$ \\
\hline & sòlอ̄6ō & $\bar{a}$ & líé & lદ́દે & $\mathrm{j} \bar{\varepsilon}$ & 10 & 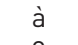 \\
\hline bic & get & TOP $3 \mathrm{SG}$ & end & 3SG.IPF & finish.IPFV & stay:NMLZ & $3 S G$ \\
\hline
\end{tabular}

'The meaning of THIS story is: if you want to get a lot of things, you end up losing.' 
The final example of the endophoric function, before I turn to the recognitional examples, is cataphoric, or indexing of subsequent referents. In the following example the demonstrative $w \bar{\varepsilon}$ is used with the proper noun Gèwūlu, the name of the main protagonist, and it is the first time ever it is introduced.

$\begin{array}{llllllllll}\text { (8) Gèwūlū } & \text { we } & \overline{\mathrm{e}} & \mathrm{k} \bar{\varepsilon} & \mathrm{g} \overline{2} & \text { dò } & \text { ká } & \text { lé } & \text { à lèē } \\ \text { Gewulu } & \text { DEM } & \text { 3SG.PST } & \text { do } & \text { man } & \text { INDEF } & \text { with } & \text { FOC } & \text { 3sG } & \text { mother } \\ \text { wà } & \text { dàā } & \overline{0} & \text { gā. } & & & & & & \\ \text { and } & \text { father } & \text { 3sG.PST } & \text { die } & & & & & \end{array}$

'THIS Gewulu was a man whose mother and father died.'

As shown above, many referents present at the interactive scene are familiar and/or discourse-old. In other words, being spatially accessible, these referents are at the same time cognitively accessible (Hanks 2011). In such cases, even if the reference is accompanied by a pointing gesture, the demonstratives $w \bar{\varepsilon}$ and $y \bar{a}$ are preferred to $t^{\prime} \bar{y}$ and $d_{\sim} \bar{a}$, which are used to index discourse-new referents. The same demonstratives $w \bar{\varepsilon}$ and $y \bar{a}$ are used for anaphoric function, which, again, is determined by accessibility of referents in mental storage (Ariel 1991). Thus, one of the central functions of these demonstratives in discourse, even when they are used exophorically, is marking that the referent is cognitively accessible and recognizable.

\section{Recognitional Deixis}

In many cases the function of the demonstratives $w \bar{\varepsilon}$ and $y \bar{a}$ is unambiguously recognitional in the narrow sense proposed by Himmelmann (1996): the referent is not present on the interactive scene and was not mentioned in prior discourse but is still identifiable by virtue of its recognizability and belonging to the common knowledge of the interactants. The following example is taken from the story mentioned in example 8 about the man whose mother and father died and who did not have the proper means to organize the funerals of his parents. Funerals are always costly, as many people are expected to show up to eat and drink. Every Mano knows what is needed for funerals: a proper amount of palm wine and a proper amount of rice, meat, and condiments. The demonstratives $b \bar{\varepsilon}$ and yéb $\bar{\varepsilon}$ (THIS wine, THIS thing) index precisely that quality of the referents: known by everybody.

$\begin{array}{llllllll}\text { (9) } K \bar{\varepsilon} & \text { ékè } & \text { c } & \text { nū } & \text { à } & \text { gèè } & \text { à } & \text { lìc } \\ \text { for.the.sake.of } & \text { better.not.to } & \text { 3PL.CONJ } & \text { come } & \text { 3sg } & \text { say } & \text { 3SG } & \text { ADR }\end{array}$




\begin{tabular}{|c|c|c|c|c|c|c|c|c|c|}
\hline & & & & & & $K n$ & $g$ Is $B$ & nging & • \\
\hline $\begin{array}{l}\text { nū } \\
\text { come }\end{array}$ & $\begin{array}{l}\text { ȳ } \\
\text { wine }\end{array}$ & $\begin{array}{l}\mathbf{b} \overline{\boldsymbol{\varepsilon}} \\
\text { DEM }\end{array}$ & $\begin{array}{l}\text { ká } \\
\text { with }\end{array}$ & $\begin{array}{l}\text { nū } \\
\text { come }\end{array}$ & $\begin{array}{l}\mathrm{p} \bar{\varepsilon} \\
\text { thing }\end{array}$ & 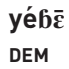 & $\begin{array}{l}\text { ká } \\
\text { with }\end{array}$ & $\begin{array}{l}\overline{\mathrm{e}} \\
\text { 3sG.PST }\end{array}$ & $\begin{array}{l}\text { wàà. } \\
\text { enter }\end{array}$ \\
\hline
\end{tabular}

'So that people don't come saying, "Bring THIS wine, bring THIS thing," he ran away.'

The following example is taken from my field notes. A woman, my host, is speaking to her contractual worker, with whom she had made an arrangement to help her with the harvest of the rice.

$$
\begin{array}{lllllll}
\text { tòò } & \text { yā, } & \text { kóò } & \text { lō } & \text { bú } & \text { yā } & \text { mè- } \dot{\varepsilon} . \\
\text { tomorrow } & \text { DEM } & \text { 1PL.IPFV } & \text { go:IPFV } & \text { rice:FOC } & \text { DEM } & \text { beat-GER }
\end{array}
$$

'THAT tomorrow, we will beat THAT rice.'

Both tòo 'tomorrow' and $6 \bar{u}$ 'rice' refer to entities made recognizable by a prior arrangement. "Everybody knows that I have to go tomorrow to my field to work," the speaker told me when I asked her to comment on her usage of the demonstrative.

Crucially, the recognitional function relies on the identifiability of the referent by both the speaker and the addressee. It may so happen that the addressee contests the identifiability and asks for more details. In the following example taken from a conversation between two best friends, the first mention of the referent was $\bar{y}$ nàáyìa $y \bar{a}$ 'that guy that bothers me', literally 'THAT bugger of mine'. However, contrary to the expectations of the speaker, the addressee did not at first recognize who was being talked about. His attempts to identify the referent are given in the following transcript:

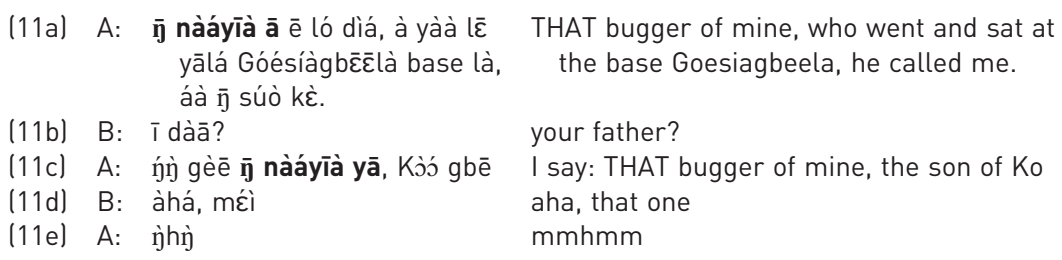

In 11a the referent is first introduced, accompanied by an indication of a place name - a military base where the man in question was stationed. In 11b, speaker B mistakenly assumes that it is speaker A's kin (classificatory father). In $11 \mathrm{c}$ speaker $A$ repeats the same identification as in 11a, 'that bugger of mine', but accompanies it with a small clarification - that he is the son of Ko (which should not help much, because Ko is the name given to a first-born daughter and, therefore, extremely common). That, however, was enough, so speaker B shows signs of recognition: 'aha, that one'. 
In the subsequent sections, I describe the abundant usage of recognitional marking in oral Bible translations. Since church service is almost exclusively monologic - with the exception of the prayers, chants, and also a brief questionresponse exchange at the beginning of each sermon - the recognitional usage can hardly ever be contested. At the same time, the speaker - a catechist, a prayer leader, or a priest - can hardly trust that everyone in the congregation, which is very heterogeneous - ranging from newcomers, who have little exposure to the Christian discourse, to older, more experienced and knowledgeable members who were converted already by the White Fathers - can identify all the referents he frames as recognizable. Rather, I claim, this recognitional usage becomes performative, as the referents are framed as if they were recognizable. More important is the type of addressee upon which the recognizability is predicated: a community of Mano Christians, (presumably) sharing a common ground.

\section{Reading That Book of Isaiah}

One of the striking features of the language of oral Bible translations into Mano is a frequent use of the demonstrative $y \bar{a} \bar{a} \sim y \bar{a} \sim \bar{a}$ in the recognitional function, as in the following example:

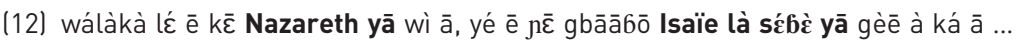

' (In) the house of God that was in THAT Nazareth, when he finished reading THAT book of Isaiah ...'

This passage is a translation of a phrase introducing Luke 4:21-30 (recorded on January 31,2016 ). Another translation of the same passage by the same speaker was given in example 1 and is repeated below with its French source and the translation of the latter into English:

(1) wálàkà lć ē $k \bar{\varepsilon}$ Nazareth ā, yé ē n $\bar{\varepsilon}$ gbāā6ō Isaie là sébè wè à à yí gèēà ká ā ...

' $(I n)$ the house of God that was in Nazareth, when he finished reading THAT speech of the book of Isaiah ...'

[En ce temps-là], dans la synagogue de Nazareth, après la lecture du livre d'Isaïe, [Jésus déclara] ...

[At that moment], in the synagogue of Nazareth, after the reading of the book of Isaiah, [Jesus declared] ...

The two translations are slightly different: while example 12 translates 'the reading of the book of Isaiah' rather closely, example 1 translates it by 'the reading of 
the speech of the book of Isaiah'. Crucially, both contain instances of recognitional marking with $(y) \bar{a}$. Example 1 has only one recognitional $\bar{a}$, 'THAT speech of the book of Isaiah'. In example 12, there are two instances of the $y \bar{a}$ demonstrative: one following the proper noun Nazareth ('THAT Nazareth') and another, following the expression Isaïe là sébè, 'THAT book of Isaiah'. All three (or two, as 'the speech of the book' and 'the book' are roughly paraphrases) referents are not present on the interactive scene and were not introduced in the prior discourse. Therefore, the most plausible function is the recognitional one: the referents are framed as known and identifiable.

Certainly, not all of the usages of $\bar{a}$ and the derivatives in the Bible translations are recognitional. Consider the following example:

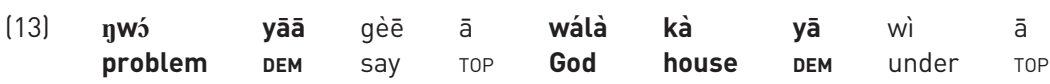

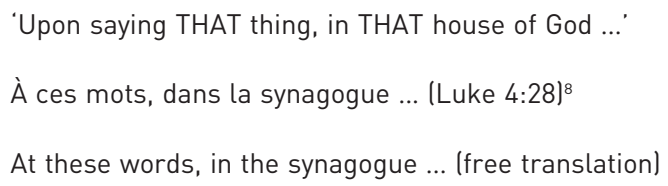

Example 13 is taken from the same translation of the excerpt from Luke (4:2130 ) as example 12 above. In the first instance, the demonstrative is used in the discourse-referential function, referring to what Jesus has just said ('THAT thing'). The second instance is anaphoric, referring to the synagogue where Jesus's reading was taking place that was first introduced in example 12.

Another example of recognitional deixis comes from Exodus 3:1 (recorded on February 28, 2016): ${ }^{9}$

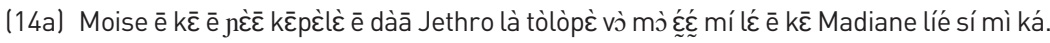

'Moses was keeping an eye on his father Jethro's domestic animals, the man who was a leader of Madiane.'

Moïse était berger du troupeau de son beau-père Jéthro, prêtre de Madiane.

Now Moses was tending the flock of Jethro his father-in-law, the priest of Midian, ... (NIV)

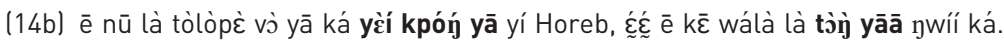

\footnotetext{
8. Here and in the following examples, the text in French indicates the textual source of the Mano translation.

9. In the following example and thereafter, NIV stands for New International Version.
} 
'He came with those domestic animals of his at THAT border of the savannah, at Horeb, that was a top of THAT mountain of God's.'

Il mena le troupeau au-delà du désert et parvint à la montagne de Dieu, à l'Horeb.

... and he led the flock to the far side of the wilderness and came to Horeb, the mountain of God. (NIV)

Example $14 \mathrm{~b}$ contains three instances of the $y \bar{a}$ demonstrative. In the first instance, the $y \bar{a}$ demonstrative that determined the noun phrase là tòlòpe vò 'his domestic animals' was used in the anaphoric function. Indeed, the domestic animals of Jethro were introduced just prior to the utterance in question, in example 14a. The other two instances are clearly recognitional because it is the first time the referents are introduced: the border of a desert and the Horeb Mountain. ${ }^{10}$

The final example, coming from Daniel 7:14 (recorded on November 22, 2015), provides evidence that my analysis of certain types of usages of demonstratives as recognitional corresponds, in fact, to the intuition of the native speakers:

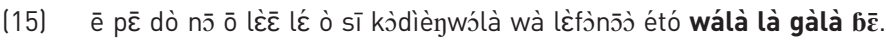

'He gave them a thing that is called power and radiance and THIS city of God.'

Et il lui fut donné domination, gloire et royauté.

He was given authority, glory and sovereign power. (NIV)

In this example the $b \bar{\varepsilon}$ demonstrative frames the noun phrase wálà là gàlà 'THIS city of God'. ${ }^{11}$ The text under discussion was recorded at one of the first church

10. Example 14 allows considering a different hypothesis of the occurrence of the markers of recognizabilitynamely, the influence of French, which all of the consulted speakers master in some degree. Indeed, instead of focusing on language-internal dynamics of the usage of recognitional marking in the translated Mano text one could suppose that it appears as an equivalent of the definite article in the source French text. However, the general patterns of phrasing show that the Mano translation is only loosely modeled after French. In 14a, the descriptive phrase la montagne de Dieu in the source text precedes the proper place name, Horeb, while in the Mano translation, the order is inverse. While in the French source, Moïse était berger is an equivalence construction ('Moses was a shepherd'), its translation into Mano is a durative construction, lit. 'Moses was keeping an eye on the domestic animals', just like in the New International Version, Moses was tending the flock. At the level of grammatical marking, the equivalence is not direct, either: in 14b, là tòlòpè vì 'his domestic animals' contains a possessive pronoun là and a plural marker $v \dot{\partial}$, the equivalents of both of which are lacking in the French source, le troupeau 'the flock'. Finally, the demonstrative does not always correspond to the definite article: in the example 11 above, Nazareth as a proper name is used without a definite article in the French source, but the translation contains a demonstrative. Therefore, it is highly unlikely that the French source influences the Mano translation at the level of the grammar. Note also that neither in French nor in English demonstratives combine with proper names. In Mano, however, such combination is quite common - see example 7. Putting aside the question of the grammatical acceptability of the combination, the semantic combination is more than natural: indeed, for Schegloff, proper nouns are recognitional expressions in themselves (1972), therefore, their compatibility with an explicit recognitional marker should not come as a surprise.

11. The example presents a case of mistranslation: a passive voice construction with a passé simple form fut 'was', 'to him was given', was translated as an active voice construction where the number values of the 
services that I attended during my fieldwork. It was before I noticed the pattern of frequent use of recognitional expressions, so I had to ask my language consultant who helped me transcribe and analyze the recordings to comment on each such use. His explanation (given in French) was, roughly, the following: $b \bar{\varepsilon}$ means either that an explanation will follow or that everybody knows that what it means is Jerusalem. ${ }^{12}$ In other words, in his own terms the native speaker construes the function of $b \bar{\varepsilon}$ as either cataphoric, introducing a referent whose identity will be elaborated in the subsequent utterances, or recognitional, introducing a referent that is identifiable by the addressee(s). Given that the subsequent text contains no explanation about the 'city of God', the only valid interpretation left is recognitional. Moreover, not only did the Mano consultant interpret the marker as recognitional ("everybody knows that"), but-as a (nonbaptized) member of the Catholic community - he also indeed recognized the reference: that the city of God is nothing else but Jerusalem.

\section{Recognizability and Speaker-Community Relationship}

The usage of recognitional deixis implies a certain information management ability that requires a position of power, and indeed, those who get to orally translate the Bible are no simple members of the community: only prayer leaders, catechists, and priests get to do it. However, not all community leaders use recognitional deixis in their Bible translations (nor do these leaders use it on every occasion). I have recorded the speech of one catechist, three prayer leaders, and two priests, and only one prayer leader and one priest show the discussed particularity. The use of recognitional markers not only belongs to a register of authoritative church discourse but is also emblematic of an in-group style of communication, not used effectively by everyone, as discussed below.

My corpus is relatively small (27 recordings of Sunday Mass or prayer, each about 2.5 hours long); I do not have the same amount of data regarding the speech of different translators (I mostly focused on one village community and

\footnotetext{
participants were mistranslated: 'he gave to them', instead of 'he was given', as in NIV. The difficulty related to the translation of this passage is apparent: a French passé simple form, which by itself belongs to the high register of literary texts and is never used in the variety of French spoken in Guinea, is coupled with another "heavy," "haughty" construction, passive voice. Other parts of the translation, however, are more accurate. The most unusual part is wálà là gàlà 'the city of God' as an equivalent of royauté 'kingship' (sovereign power in NIV). This Mano translation conveys a more specific idea than the original: what was given was not only sovereign power in general but (the power over) the city of God. The idea is perfectly consistent with the content of the prophecy. This translation shows that while the Mano translator went off the literal meaning of the text, he nonetheless produced an equivalent corresponding to the conveyed meaning.

12. The note that I made of the comment is the following: "si on dit $w \bar{\varepsilon}$, normalement soit on s'attend à une explication devant, ou bien tout le monde connaît que ce que cela veut dire est Jérusalem."
} 
one prayer leader, Christophe); and, most of all, nearly all the texts are translations of different excerpts and, therefore, are incommensurate. However, I managed to obtain some translations of the same excerpts that convincingly show the differences in speech patterns of at least some speakers. Consider example 16, which compares the speech of two prayer leaders, first Christophe and then Augustin (recorded on February 21, 2016):

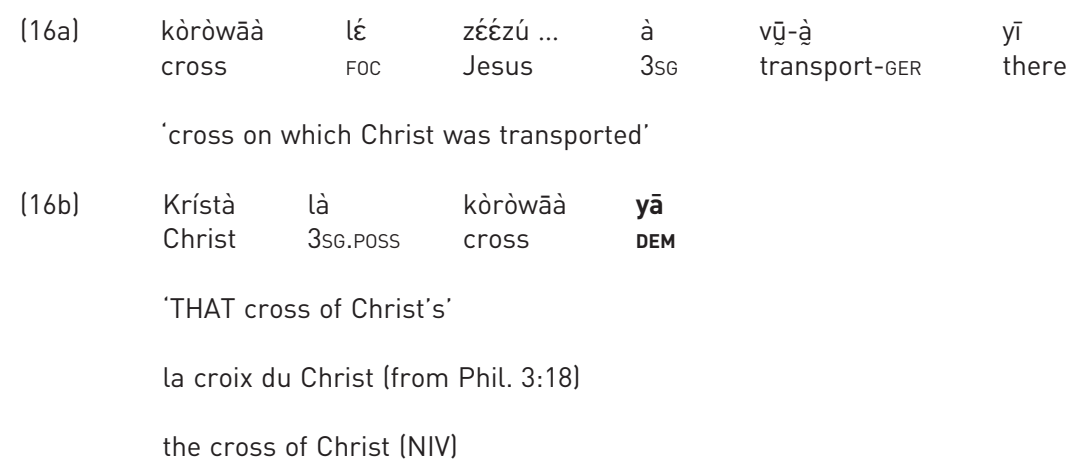

Only prayer leader Augustin uses the recognitional marker (16b: 'THAT cross of Christ's'), while Christophe does not ('cross on which Christ was transported'). Another example illustrates the same pattern of the two prayer leaders (Christophe, then Augustin):

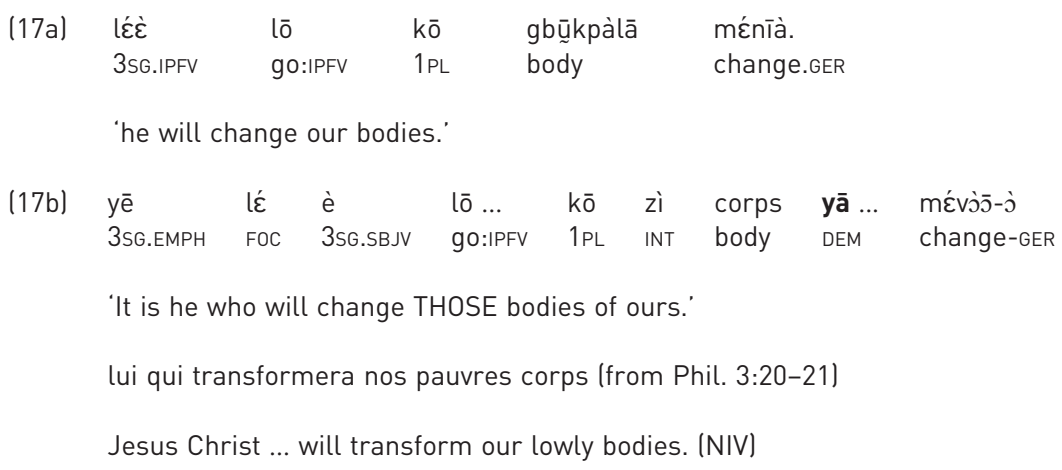

Here, again, only prayer leader Augustin uses the $y \bar{a}$ marker. In addition, all the previously discussed examples of recognitional deixis in the church register are taken from the speech of the two prayer leaders, but only example 15 comes from the speech of prayer leader Christophe, while the three instances of recognitional marking in examples 1,12 , and 14 come from the speech of Augustin. 
The following examples illustrate the particularities of the speech of two Mano-speaking priests. The examples come from the translations of the Gospel of Luke that were read on Christmas Eve in 2015 and 2017 by priests Jean-Pierre and Élie, respectively:

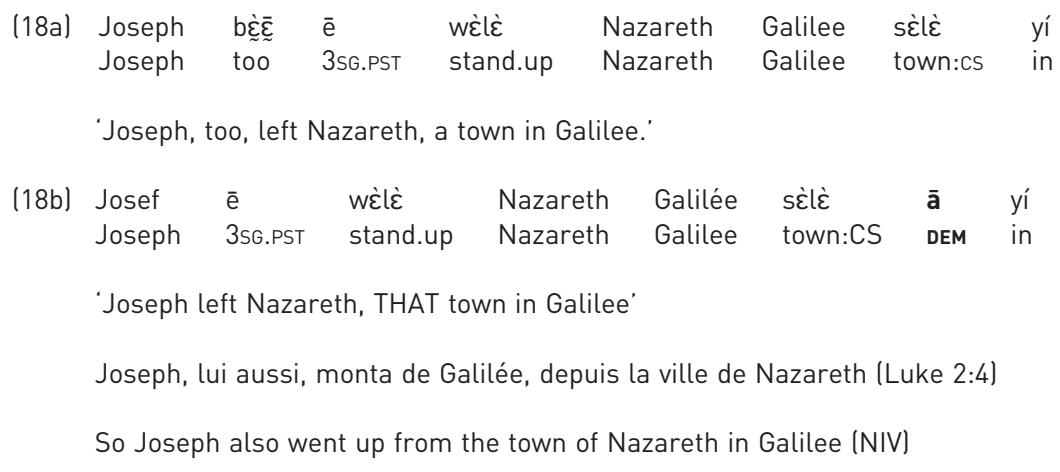

Example 18 is the clearest illustration of the style differences: the wording is

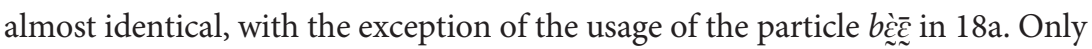
one priest, Élie, uses the recognitional marker (18b). Example 19 is yet another illustration of the same pattern; compare the wording of Jean-Pierre, followed by that of Élie:

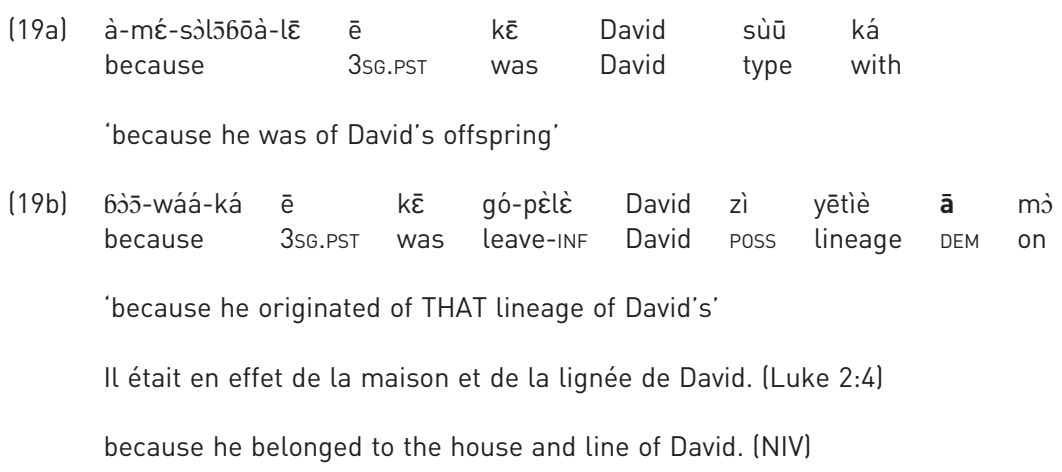

There are indications in the social background of the speakers that may be held responsible for the difference in their style. In the case of the two prayer leaders, there are differences in the socioeconomic background: Christophe is a simple farmer, while Augustin, who uses recognitionals most, is a former school teacher now concentrating on his plantation's management. Augustin is relatively well off, which is always seen in his new outfits and a beautifully adorned cross that he 
wears but also in his habit of having a morning coffee before leading a Sunday celebration. The chapel where Augustin preaches was built by his community, which takes pride in it. Christophe's church was built with the help of a donation from an important Mano official, and before 2017 there was no dedicated church building; Sunday celebrations were organized in a school. In addition, Augustin preaches in his own native village, while Christophe preaches in a village 10 kilometers away from his native village, where he came to replace an authoritative catechist after the death of the latter. In addition, Christophe's wife originates from that village.

As for the two priests, they are on the same socioeconomic level. Élie, whose speech is defined by recognitional markers, was trained and ordained in France. He was born in Liberia, but his father was from Guinea, the village where Élie later went to school and where he served the Christmas Mass of 2017 (the source of the excerpts cited above). As a boy and a young man, he was very close to the late and very influential catechist Alfred. Several weeks prior to Christmas Eve, the village hosted major celebrations in honor of his (and another priest's) ordination. Although he does not reside in Guinea (a couple days after Christmas he had to head to Chad, to the parish he was assigned to), he is well known, highly esteemed, and much talked about by the community. Indeed, I had heard much about him during my visit in 2015-16 before actually meeting him in 2017. As for Jean-Pierre, he is an important church official: in addition to his service as a priest, he is the financial director (économe) of the diocese of Nzerekore, which is the ecclesiastic (and also administrative) capital of the whole of Forest Guinea. He also travels often to Europe and studied in Lyon while serving in a small parish. However, while Jean-Pierre's mother is Mano, his father is Kpelle, Jean-Pierre has a Kpelle name, and the parishioners sometimes mock his Kpelle accent. ${ }^{13}$

It seems that the crucial factor contributing to the choice to use the recognitional markers is not so much the general position of authority that the role of a prayer leader (or a priest) provides, nor some reinforcement by the socioeconomic capital that the speakers possess outside the church. More important seems to be the relationship between a prayer leader (or a priest) and his community, and especially whether they are local to the community or not. Note that both Augustin and Élie are considered local: Augustin serves in his native village, while Élie serves in the village that adopted him as a child. Both Christophe and Jean-Pierre are foreign to the church communities to which the Bible translations were addressed. While Christophe preaches to the village of his in-

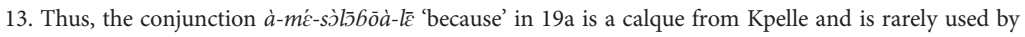
monolingual Mano speakers. 
laws, Jean-Pierre is a foreigner in yet another sense: although he speaks Mano perfectly well, he is considered ethnically Kpelle. Therefore, the possibility of management of common ground, needed for the use of recognitional markers, appears to be dependent on the existence of a privileged access to the community and in-group membership within it.

Some stylistic variation can be observed when the same speaker addresses different communities. Thus, when Augustin serves in his native village, he uses slightly more recognitionals than when he visits a neighboring village some 5 kilometers away. Examples 1 and 12, translations of the same passages, are illustrations of this kind of variation: example 1, which has only one recognitional, was obtained from a recording of Augustin's visit to a neighboring village, while example 12, which has two recognitionals, was obtained in his home village. In examples 20a and 20b below, recorded on January 31,2016, the same tendency is observed: 20a, recorded on Augustin's visit, contains one recognitional, while 20b, recorded in his home village, contains two recognitionals:

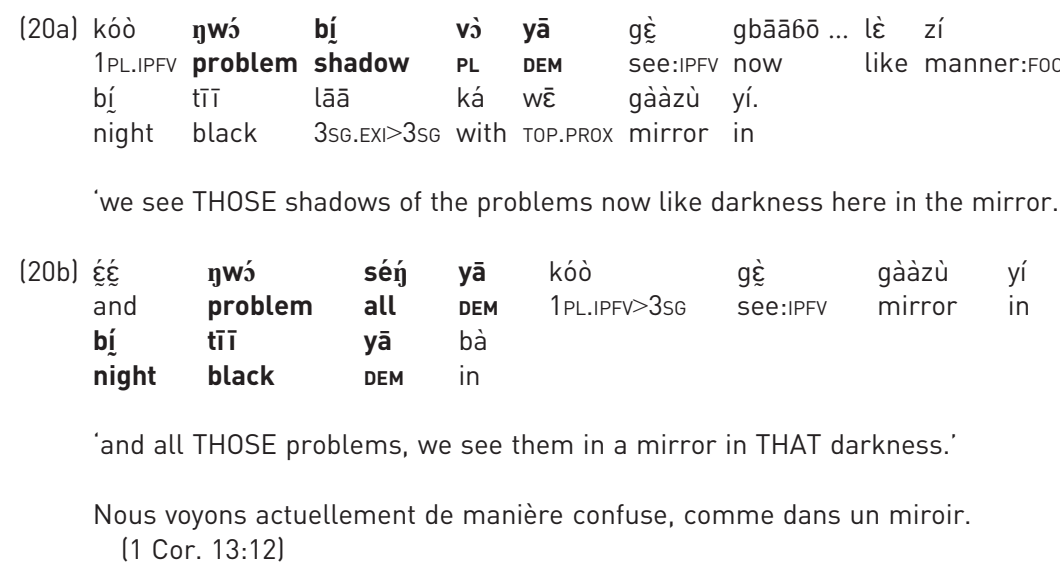

For now we see only a reflection as in a mirror. (NIV)

The use of recognitionals is not an automatic function of social context. Augustin uses them extensively even when he preaches outside his native village (examples 16 and 17 come from a recording of one of his visits). In contrast, Christophe almost never uses recognitionals even when he serves in his own village. Moreover, the third prayer leader and the only catechist whose speech I studied do not use recognitionals, but both preach in their native villages. Therefore, the social context provides a necessary, but not a sufficient, condition for the use of recognitional markers. 


\section{Discussion: Performative Projection of Common Ground and Religious Community}

Demonstratives used in the recognitional function point to objects recognizable by virtue of the interactants sharing some common ground. In English, that is commonly used in the recognitional function: this is, for instance, the function of that in Spin that wheel, the formula vocalized by the entire Paramount Theatre in Oakland, California. Or this is the function behind the name of a Mac repair shop in Berkeley, California, Fix That Mac. Or, more importantly still, this usage is behind the marketing strategy of the Cliff House souvenir shop in San Francisco: "Pick Up That Special Gift or Souvenir for That Special Person." In the Spin that wheel case, recognitional markers are used to refer to some preexisting pieces of context, more specifically, common knowledge: before the movie starts, there is a lottery accompanied by a spinning of the wheel of fortune, and all the frequenters of the Paramount Theatre know it. In other words, the existence of the referent the knowledge of which is shared (THAT wheel) is presupposed (Silverstein 1976, 33). Similarly, all the users of old Macs will recognize themselves as addressees of Fix That Mac. But what about That Special Gift and That Special Person? Did they really exist before the reader of the advertising - it was printed on a Cliff House café menu-felt the urge to go shopping?

According to Silverstein, different types of indexicals, such as honorifics, have a context-creating performative function, including the pronominal usage, described in the beginning of this article. Several studies of grammar in interaction point to that context-creating capacity of grammatical indices. Thus, $\mathrm{Mu}-$ shin talks about stance-taking in the adoption of the evidential strategy and the way it shifts the epistemic authority: "Not only may the assertion of direct visual experience be an expression of certainty, it may also be part of a claim to a high degree of epistemic authority over the information" $(2012,104)$. Similarly, in her study of demonstratives in Finnish with special attention to the recognitional function (which she frames in terms of marking of identifiability), Laury points out that "demonstratives not only express context, they also build context" $(1997,58)$.

Indeed, the recognizability of specific referents may be a result of performative framing of them as recognizable. As in the case of that gift for that special person, even if a visitor didn't have a special person before coming to the gift shop, nor the intention to buy a gift for anyone, she may need to make an effort to resist the need, triggered by the advertisement, to search for a souvenir and a person to make happy. 
Recognitional marking of noun phrases is ubiquitous in the speech of certain Mano Catholics. Typically framed as recognizable are some key Christian referents: the book of Isaiah; the Cross; the line of David; in examples not given here, even Jesus and God sometimes receive recognitional marking. There are a few more puzzling examples: such as 'our bodies' or 'the darkness'. A common type of recognizable referent is place names: we saw Nazareth (also referred to 'the city of God', or, in examples not given here, just 'the land'), the country of Galilee, and, most surprisingly, the Horeb mountain and the (unspecified) border of a desert.

Claiming (and framing) the Horeb mountain or the border of a desert as recognizable would be counterintuitive at best, if not outright counterfactual (Deppermann 2015). In example 1 we saw that the recognitional marker framed the expression "the speech of the book of Isaiah" - the content of which was beyond the scope of the reading at hand. A more plausible interpretation of the indexical function of recognizability is not that it presupposes common knowledge of referents, but rather that it performatively establishes the presupposition of common knowledge.

In the Mano examples discussed above, presupposition of common knowledge of referents is unnecessary for any language-internal functional purposes, such as establishing discourse coherence. The referents are hardly ever mentioned more than once in a given chunk of discourse - a reading from the Bible - and do not help push the narrative further. It is obvious, then, that accommodating, ${ }^{14}$ against the context at hand, of a presupposition of referent knowledge does something other than just enriching a pool of preexisting presuppositions. I argue that it serves a different purpose: establishing religious common ground and, through that, the community that shares that common ground.

I now proceed to a theoretical discussion arguing that recognitional marking could be seen not as indexing of specific properties of context - mutually known referents as part of the common ground-but rather performatively projecting contextual features, namely, the existence of common ground and of the community sharing that common ground. I have already argued that recognitional

14. Performatively established presupposition — and ways the addressees deal with it—is discussed in analytic philosophy under the term "presupposition accommodation" (Lewis 1979; Beaver and Geurts 2014). A typical example is Betty is trying to give up drinking: in order to make sense of the utterance, the addressee must assume that Betty used to drink. In other words, the utterance triggers the presupposition that Betty used to drink. In case the current conversational context did not provide grounds for such presupposition - if Betty's drinking was not discussed - then the addressee is expected to accommodate this presupposition and extend the pool of presuppositions accordingly (Karttunen 1974, 191). 
deixis has a context-creating performative capacity. I will now formulate an approach linking religious conversion to religious common ground, and common ground to community building. Then I suggest looking at the assertion of common knowledge as a performative strategy. Finally, I focus on the way common ground projection becomes a function of propositional stance and the way it shapes, and reflects, social relationships.

According to Talal Asad, in medieval Christianity, "the authoritative discourses, the teachings and practices of the Church" (and the discipline through which they came to be imposed) had a primacy over "the convictions of the practitioner" (1993, 39). According to Asad, in medieval Christianity belief was built on practical and theological knowledge. "Familiarity with all such (religious) knowledge was a precondition for normal social life, and belief (embodied in practice and discourse) an orientation for effective activity in it" $(1993,47)$.

While belief as a private disposition may still play an important role for a member of a contemporary Christian community (especially, perhaps, in Protestantism), all Christian practice inevitably involves a considerable amount of specialized knowledge. In medieval to modern Catholicism, the church space has a precise structure, the core elements of which remain invariant, such as the crucifix, spaces dedicated to the priest or the prayer leader, a space for the choir, a space for the congregation. Similarly, speech is an important part of the Christian common ground, as much of the verbal part of a Christian ritual, such as prayers, is predetermined and learned by heart by the community.

On a more general level, membership in a community always entails knowledge sharing. In speech communities, people share the language; in a village, people also share knowledge about local history, geography, and folklore; kinship systems; social structure; the structure of living, ritual, and agricultural spaces (Hanks 1990). On an interpersonal level, people track earlier conversations and joint experience. "'Common ground' is the sum of the information that people assume they share" (Clark 2006, 105). Common ground rarely becomes explicit; however, it underlies virtually all everyday activity. In the same way that community membership involves having common ground, common ground can serve as a definition of a social community: "the subjective meaning the group has for its members consists in their knowledge of a common situation, and with it of common system of typifications and relevances" (Schutz 1970, 82; see also Enfield 2006, 2013). Similarly, practical and theological knowledge, but also mental or corporeal dispositions, may be seen as a common ground of religious practitioners, and much of the verbal and nonverbal activity may be predicated on a presupposition of such knowledge. 
In contrast to Clark, who takes common ground for granted, as something already there, albeit at the level of mutual assumptions, I argue that the presupposition of common knowledge does not have to be given (on a similar point, see Hanks [2006]). Instead of presupposing common ground assessed by interlocutors on the basis of their knowledge of a situation - for example, community co-membership - linguistic expressions, such as recognitionals, may instead project common ground. I will now discuss the work by Yurchak (2005), who make a similar type of argument.

One of the foci of Yurchak's (2005) book is increasing uniformity and predictability of official language of the late Soviet period. One of the key communicative features of the official language was that all types of information, new and old, were presented as knowledge previously asserted and commonly known. In linguistic terms, information was presented as presupposed. That backgrounding and presupposing of information was achieved not only on the discourse level (such as manifest intertextuality, as well as narrative and rhetorical circularity) but also at the level of grammar (see also Nichols 1988).

One of the formal features through which such backgrounding was framed was the use of complex modifiers. Thus, the complex expression "the high level of social consciousness" tricks the reader into perceiving "social consciousness" as already existing, as a known fact rather than a contested claim. Indeed, "to be high, social consciousness must exist, and to be measured comparatively, by levels (high level, low level), it must exist.” (Yurchak 2005, 66).

While Yurchak places the performative dimension of authoritative discourse at the level of production and reception, arguing that texts were divorced from literal, constative meaning and used ritually, I suggest that the performative momentum starts already in the choice of the form. Indeed, framed as presuppositions, "ideas are treated as obvious, taken-for-granted facts, without necessarily being such" (Yurchak 2005, 66). It is the very framing of ideas as presuppositions that creates the performative effect of the "taking-for-granted" of a piece of information, presenting it as universal truth.

Yurchak argues that information backgrounding served the purpose of discourse anonymization and transformation of the authors into mediators of previously established knowledge and universal truth. In addition to that, I argue that in Bakhtinian terms, presupposition creation can be claimed to have a dialogic nature. Indeed, when a speaker frames a piece of information as given and known, it must be known not only to the speaker, but also assumed to be known (or performatively established as known) to the addressee. The addressee in Yurchak's case, given the omnipresent character of official discourse in the So- 
viet Union, is the majority of the country's population - those who adhere ritually to the form of official discourse. Therefore, the propagation of normalized, standardized official discourse grounded in implicit presuppositions created not only an anonymized author-mediator but also a uniform public implicitly adhering to these presuppositions (what Yurchak calls svoi, the co-members of a social formation). Similarly, by performatively framing information as presupposed and part of the common ground, a Mano priest or prayer leader creates a collective that shares that common ground. In other words, the operation of projection of common ground becomes an operation of community projection.

Performative presupposition does not operate at the level of a single utterance or even a single text. The portability, citationality, and replicability in the case analyzed by Yurchak make individual operations on presuppositions, at the constative level of the language, much less important than their prominence at the level of the register as a whole. In the Mano case, although certain, but not all, recognitional expressions make sense individually - as they index referents that can be considered prominent in Christian doctrine, such as Nazareth or the book of Isaiah — framing of some of the referents as recognizable — such as the Horeb mountain or, even more so, an unspecified border of an unnamed desertis counterintuitive, if not counterfactual. However, regarded from the performative angle, common ground projection should not be treated in any literal, content-based sense. Moreover, a specific choice of referring expression-marking of noun phrases as known and recognizable by the interlocutors - is made by some speakers more frequently than by others. Given the ubiquity of recognitionals in the speech of certain individuals, recognitionals are best described as a feature of an in-group verbal style and a propositional stance that certain speakers tend effectively to employ (Agha 2006, 96).

The propositional stance is not arbitrary but is emblematic of in-group relations between speaker and hearer in specific communicative situations, as evaluated through a membership analysis, namely "an evaluation of the social category of hearer; or the relative membership of speaker and hearer in some social category (e.g., whether same or different)" (Schegloff 1972; Agha 2006, 95). Indeed, prayer leader Augustin, with his good stature, new motorbike, beautiful cross, and, especially, a well-functioning church community in his home village, may have good reasons to project that sense of belonging together-perhaps also in the face of an active Evangelical church just across the street. Similarly, Élie, a young priest fresh from ordination, having spent many years in parishes abroad, addresses a welcoming community (of his village and of other villages in the area) who are proud to finally have a truly Mano priest and project back 
a strong community bond. Thus, recognitionals not only indexically project the presupposition of recognizability of referents but, through this projection, also formulate the participation framework of communication as an in-group community of knowledge-sharing co-insiders. Crucially, the availability of the indexical projection depends on an independently preexisting relationship between speaker and hearers, upon which the performance laminates an additional sense of co-membership in a community, in this case a religious community.

\section{Conclusion}

This article is grounded in a fine-grained discussion of grammatical data, namely, the usage of demonstrative markers in the Bible translations orally produced by Mano priests and prayer leaders. A previously understudied genre, these texts are shown to be intrinsically related to the context of their production, as the patterns of usage of demonstrative markers depend on the social position of the speakers and their relationships with the church community. The argument focuses on a specific value of these demonstratives: the so-called recognitional function, which is used when a demonstrative frames a referent whose knowledge the speaker assumes to share with his or her addressee as part of their common ground. This usage of demonstratives occurs in routine conversations, whereby the addressees have the opportunity to contest and negotiate the recognizability of the referents. In the church, by contrast, where the speech production is mostly monologic (and where the Bible translation is exclusively monologic), the recognizability is never contested. In many cases, however, the referents cannot be recognized by many, if not all, members of the congregation, which adds a performative dimension to the recognitional usage: the referents do not actually have to be known by everybody, but they are presented as if they were known. ${ }^{15}$ Moreover, due to their ubiquity in the speech of certain individuals, recognitional demonstratives in part lose their function of marking recognizability of individual referents and become a stylistic feature.

On a different level, I argue that the assertion of common knowledge in Bible translation is tied to the fact that religious conversion implies acquisition - and sharing - of practical and doctrinal knowledge. As with any community, a religious community gets to share a considerable amount of common ground,

15. The analysis of performativity of demonstratives in Mano in its present stage lacks a crucial aspectthe uptake by the addressee(s). While the church speech is mostly monologic, there is hardly any question of uptake directly following the enunciation. Long-term effects of uptake, such as the emergence of a steady body of common knowledge; or the further spread of recognitional deixis as a feature of a style of communication or even group register should be an object of future studies. 
which in part defines its very existence. By performatively projecting the presupposition of common knowledge, the ritual specialist, a priest or a prayer leader, at the same time brings about the community that shares this knowledge and formulates an in-group relationship with this community. Crucially, it is only if a ritual specialist already has some privileged ties with his village community that he may resort to performative presupposition management and reinforce that community in speech. Thus, through a delicate two-way operation of a reflection of contextual relationship and at the same time a projection of that relationship, recognitional deixis contributes to a discursive formation of a religious community, which emerges through common activities ("groupwork") but also as a community of co-insiders sharing a common ground. The performative "magic" of the indexical projection does not create community ex nihilo but predicates it on relationships existing on independent grounds. As a word of warning from Pierre Bourdieu, particularly relevant for the present context: "One only preaches to the converted. And the miracle of symbolic efficacy disappears if one sees that the magic of words merely releases the 'springs' - the dispositions_-which are wound up beforehand” (Bourdieu 1991, 126).

\section{References}

Agha, Asif. 2006. Language and Social Relations. Studies in the Social and Cultural Foundations of Language 24. Cambridge: Cambridge University Press.

Ambroise, Bruno. 2009. "Une conception non-scolastique de l'efficacité linguistique: Bourdieu lecteur d'Austin." In Pierre Bourdieu, un philosophe en sociologie, ed. A.-M. Lescourret, 65-88. Paris: PUF.

Ariel, Mira. 1991. "The Function of Accessibility in a Theory of Grammar." Lournal of Pragmatics 16:443-63.

Asad, Talal. 1993. Genealogies of Religion: Discipline and Reasons of Power in Christianity and Islam. Baltimore: Johns Hopkins University Press.

Austin, John L. 1962. How to Do Things with Words. Cambridge, MA: Harvard University Press.

Beaver, David I., and Bart Geurts. 2014. "Presupposition." In The Stanford Encyclopedia of Philosophy, ed. Edward N. Zalta. https://plato.stanford.edu/archives/win2014/entries /presupposition/.

Bourdieu, Pierre. 1991. Language and Symbolic Power. Oxford: Polity.

Clark, Herbert H. 2006. "Context and Common Ground.” In Encyclopedia of Language and Linguistics, ed. Keith Brown, 2nd ed., 105-8. Oxford: Elsevier.

Comaroff, Jean, and John L. Comaroff. 1991. Of Revelation and Revolution. Vol. 1, Christianity, Colonialism, and Consciousness in South Africa. Chicago: University of Chicago Press.

Deppermann, Arnulf. 2015. "When Recipient Design Fails: Egocentric Turn-Design of Instructons in Driving School Lessons Leading to Breakdowns of Intersubjectivity." Gesprächsforschung 16:63-101. 
Derrida, Jacques. 1986. "Declaration of Independence.” Translated by T. Keenan and T. Pepper. New Political Science 15:3-19.

Diessel, Holger. 1999. Demonstratives: Form, Function and Grammaticalization. Amsterdam: John Benjamins.

Enfield, Nick J. 2006. “Social Consequences of Common Ground.” In Roots of Human Sociality. Culture, Cognition and Interaction, ed. Nick J. Enfield and Stephen C. Levinson, 399-430. Oxford: Berg.

- 2013. Relationship Thinking: Agency, Enchrony, and Human Sociality. Oxford: Oxford University Press.

Foster, Elizabeth Ann. 2008. Faith in Empire: Religion, Politics, and Colonial Rule in French Senegal, 1880-1940. Stanford, CA: Stanford University Press.

Friedrich, Paul. 1972. "Social Context and Semantic Feature: The Russian Pronominal Usage." In Directions in Sociolinguistics: The Ethnography of Communication, ed. John J. Gumperz and Dell Hymes, 270-300. New York: Holt, Rinehart \& Winston.

Handman, Courtney. 2014. Critical Christianity: Translation and Denominational Conflict in Papua New Guinea. Berkeley: University of California Press.

Hanks, William F. 1990. Referential Practice: Language and Lived Space among the Maya. Chicago: University of Chicago Press.

—. 2005. "Explorations in the Deictic Field." Current Anthropology 46 (2): 191-220.

. 2006. "Joint Commitment and Common Ground in a Ritual Event." In Roots of Human Sociality. Culture, Cognition and Interaction, ed. Nick J. Enfield and Stephen C. Levinson, 299-328. Oxford: Berg.

- 2010. Converting Words: Mava in the Age of the Cross. Berkeley: University of California Press.

- 2011. "Deixis and Indexicality." In Foundations of Pragmatics, ed. Wolfram Bublitz and Neal R. Norrick, 315-46. Berlin: Mouton de Gruyter.

Himmelmann, Nikolaus P. 1996. "Demonstratives in Narrative Discourse: A Taxonomy of Universal Uses.” In Studies in Anaphora, ed. Barbara A. Fox, 205-54. Amsterdam: John Benjamins.

Horton, Robin. 1971. “African Conversion.” Africa 41 (2): 85-108.

1975a. "On the Rationality of Conversion: Part 1." Africa 45 (3): 219-35.

1975b. "On the Rationality of Conversion: Part 2." Africa 45 (4): 373-99.

Karttunen, Lauri. 1974. "Presuppositions and Linguistic Context." Theoretical Linquistics $1: 181-94$.

Khachaturyan, Maria. 2015. “Grammaire du Mano.” Mandenkan 54:1-252.

Laury, Ritva. 1997. Demonstratives in Interaction: The Emergence of a Definite Article in Finnish. Amsterdam: John Benjamins.

Lee, Benjamin. 1997. Talking Heads: Lanquage, Metalanguage, and the Semiotics of Subjectivity. Durham, NC: Duke University Press.

Lelong, Maurice-Hyacinthe. 1949. N’zérékoré: L'Évangile en Forêt Guinéenne. Paris: Librairie missionnaire.

Lewis, David. 1979. "Scorekeeping in a Language Game." Lournal of Philosophical Logic 8:339-59.

Loua, Zaoro Hyacinthe. 2008. Le Christ en Guinée-Forestière: Évangélisation et actes des premiers chrétiens Kpellè. Abidjan: CERAP. 
Mushin, Ilana. 2012. "'Watching for Witness': Evidential Strategies and Epistemic Authority in Garrwa Conversation." Pragmatics and Society 3 (2): 270-93. https://doi.org/10.1075 /ps.3.2.07mus.

Nichols, Johanna. 1988. "Nominalization and Assertion in Scientific Russian Prose." In Clause Combining in Grammar and Discourse, ed. John Haiman and Sandra A. Thompson, 399-428. Philadelphia: John Benjamins.

Robbins, Joel. 2004. Becoming Sinners: Christianity and Moral Torment in a Papua New Guinea Society. Berkeley: University of California Press.

Rosier-Catach, Irène. 2004. La parole efficace: Signe, rituel, sacré. Paris: Éditions du Seuil.

Schegloff, Emmanuel A. 1972. "Notes on a Conversational Practice: Formulating Place." In Studies in Social Interaction, ed. David Sudnow, 75-119. New York: Free Press.

Schieffelin, Bambi B. 2007. "Found in Translating: Reflexive Language across Time and Texts." In Consequences of Contact: Language Ideologies and Sociocultural Transformations in Pacific Societies, ed. Miki Makihara and Bambi B. Schieffelin, 140-65. New York: Oxford University Press.

—. 2014. "Christianizing Language and the Dis-placement of Culture in Bosavi, Papua New Guinea." In "The Anthropology of Christianity: Unity, Diversity, New Directions." Current Anthropology 55 (S10): S226-S237.

Schutz, Alfred. 1970. On Phenomenology and Social Relations: Selected Writings. Ed. Helmut R. Wagner. Chicago: University of Chicago Press.

Silverstein, Michael. 1976. "Shifters, Linguistic Categories and Cultural Description." In Meaning in Anthropology, ed. Keith H. Basso and Henry A. Selby, 11-55. Albuquerque: University of New Mexico Press.

- 2003. Talking Politics: The Substance of Style from Abe to "W." Chicago: Prickly Paradigm Press.

Tambiah, Stanley Jeyaraja. 1985. Culture, Thought and Social Action: An Anthropological Perspective. Cambridge, MA: Harvard University Press.

UBS (United Bible Societies), ed. 1978. New Testament in Mano: Translation by June M. Hobley Jackson and Stanley Younguoi. Monrovia: United Bible Societies in Liberia.

Vieira, Gérard. 2005. Sous le signe du laïcat: Documents pour l'histoire de l'Eglise Catholique en Guinée. Vol. 3, L'église Catholique en Guinée à l'épreuve de Sékou Touré, 1958-1984. Paris: Karthala.

Yurchak, Alexei. 2005. Everything Was Forever, until It Was No More: The Last Soviet Generation. Princeton, NJ: Princeton University Press. 